\title{
Nanoencapsulation of Biologically Active Peptides from Whey Proteins
}

\author{
Burcu Cabuk $^{1}$, Burcu Okuklu ${ }^{1}$, Nicoleta Stanciuc ${ }^{2}$ and Sebnem Tellioglu Harsa ${ }^{1 *}$ \\ ${ }^{1}$ Department of Food Engineering, Faculty of Engineering, Izmir Institute of Technology, 35430, Gulbahce Koyu, Urla, Izmir, Turkey \\ ${ }^{2}$ Dunarea de Jos University of Galati, Faculty of Food Science and Engineering, Domneasca Street 111, 800201 Galati, Romania
}

\author{
Received: March 26, 2014; Accepted: June 18, 2014; Published: June 24, 2014 \\ *Corresponding author: Sebnem Tellioglu Harsa, Department of Food Engineering, Faculty of Engineering, Izmir Institute of Technology, 35430, \\ Gulbahce Koyu, Urla, Izmir, Turkey, Tel.: (0232) 75062 91;Fax.: +90 232750 6196; E mail: harsasebnem@gmail.com
}

\begin{abstract}
Now a days consumers, in order to feed with balanced diet prefer healthy and reliable foods. In this respect food manufacturers are trying to respond the demands of consumers by developing new types of foods such as diet foods ( low calorie foods), modified foods (organic foods) and functional foods (probiotic and prebiotics). Thus, production of nutritious, functional and beneficial foods has become a growing sector in the United States and European countries.

Proteins are major source of many bioactive peptides. Bioactive peptides have been defined as specific protein fragments that have a positive impact on body functions and may ultimately influence human health. These peptides stay inactive within the main protein structure and activated by the enzymatic hydrolysis. These bioactive peptides, derived from proteins, are able to influence basic body systems (cardiovascular, nervous, gastrointestinal and immune systems) and show multi-functional character.
\end{abstract}

Due to these properties, studies have recently been focused on milk proteins and their bioactive peptides. Such peptides are inactive within the sequence of the milk protein. Whey contains a multitude of biologically active proteins and peptides.

Physiologically active serum proteins are serum albumin, immunoglobulins, proteose-peptone, lactoferrin, lactoperoxidase and growth factors. In addition to these, enzymatic degradation of serum proteins releases a number of bioactive peptides such as alfa-lactophorin, beta-lactophorin, beta- lactotensin, lactokinin, albutensin, serophorin and lactoferricin.

One of the common qualities of bioactive substances is their sensitivity to the physical and chemical properties of the environment. For this reason, the usefulness of bioactive components in food is limited by the structure. In order to sustain bioavailibility of these peptides, limiting its relationship with the media by encapsulation technology is one of them osthotly debated issues on in recent years.

Keywords: Nanoencapsulation; Bioactive peptides; Whey

\section{Introduction}

In the last few years the food crises associated to the unstable world economy and climate changes became a global food security challenge. In these circumstances, the concern related to protein malnutrition in direct relation with growing world population has increased.
Now a days, consumers call for being informed about raw materials origin, processing technologies, nutritional bioavailability and also about food influences on health and disease prevention. The increased development of national and international food market and its globalization, could explain the increased attention paid to the food quality, safety and authenticity issues. The ultimate scientific goal in food science and food industry is to relate molecular properties to food properties, along the entire food chain. The amount of information that has to be linked together is enormous. However, the food properties will depend on the properties and interactions of the microstructural elements.

Their properties and interactions subsequently depend on the molecular properties of the ingredients. It is the description on the level of the micro-structural length scale that is enabling to diminish the amount of information necessary to describe food properties in terms of molecular properties of its ingredients. The micro-structural information is therefore key for relating molecular to macroscopic properties.

Benefits of whey proteins in food applications include its high protein and amino acid content; low calorie, fat, and sodium content; lack of pathogens, toxic compounds, and antinutritional factors; good emulsification capacity; compatibility with other ingredients; ready availability; and the perception that it is a "natural" product [1].

Hydrolyzed whey protein-based formulas are beneficial for infants intolerant to cow's milk protein. During hydrolysis proteins are broken down into peptides of different sizes and free amino acids, as a result of cleavage of peptide bonds. Enzymatic hydrolysis developed under mild conditions of $\mathrm{pH}$ (6-8) and temperature $\left(40-600^{\circ} \mathrm{C}\right)$ may also lead to the development of the biologically active nutritional components like bioactive peptides to promote health-giving opportunities for the use of dairy ingredients. Control of the molecular size of resultant peptides constitutes an essential step in the development of protein hydrolysates for dietary use.

\section{Bioactive Peptides of Whey Origin}

Milk proteins are considered to be the one of the most 
significant source of bioactive peptides. Whey protein hydrolysates may offer a number of excellent nutritional characteristics and functional properties. Whey proteins constitute approximately $20 \%$ of milk proteins. Most important whey proteins include $\beta$-lactoglobulin, $\alpha$-lactalbumin, serum albumin and immunoglobulins. Resulting biologically active protein or peptide fractions from hydrolysis or separation of serum proteins can be used in the production of functional foods. serofin, laktoferroksin, $\alpha$-laktorfin, $\beta$-laktorfin, albutensin A ve $\beta$ - laktotensin are main examples of bioactive peptides derived from serum proteins.

Bovine whey proteins consist mainly of $\beta$-lactoglobulin $(\beta-L G)$ and $\alpha$-lactalbumin ( $\alpha$-LA), but also of serum albumin, immunoglobulin, lactoferrin and minor constituents. $\beta$-LG is the major whey protein in milk of ruminants and many other mammals. Under physiological conditions (neutral $\mathrm{pH}$ and concentration $>50 \mathrm{mM}$ ) $\beta$-LG exists as a dimer [2-4]. The interaction region for dimerization is near a $\alpha$-helical rod between residues Asp129 and Ala142, which is close to the free thiol group (Cys121) of the monomers [5]. The dimer starts to dissociate into two identical monomers above $\mathrm{pH} 6.5$ and below pH 3.5. Monomeric $\beta$-LG consists of 162 amino acids, and has a molecular weight slightly around $18,300 \mathrm{Da}$. The secondary structure of the monomer consists of three short helices, an $\alpha$-helix, and nine strands of anti-parallel $\beta$-sheets. The secondary and tertiary structures of the monomers are stabilized by hydrophobic, ionic and hydrogen bond interactions between the peptide chains, as well as by two disulphide bridges. In native $\beta$-LG the disulphide bridges (Cys66-Cys160 and Cys106-Cys119) and the free thiol group (Cys121) are inaccessible to solvent. The free thiol group and the disulphide bond Cys106-Cys119 are in a hydrophobic cleft between two $\beta$-strands, and are covered by the $\alpha$-helix [6-8]. $\beta$-LG is stable against stomach acids and proteolytic enzymes, is a rich source of the essential acid cysteine, and may be responsible for carrying the vitamin A precursor retinol from the cow to its calf [9]. $\alpha$-LA, which binds calcium, is similar to the primary protein in human breast milk and is thus used in infant formula. The many branched-chain amino acids it contains are used by muscles for energy and protein synthesis, making it a popular sports food nutrient [10]. $\alpha$-LA is a small acidic $\mathrm{Ca}^{2+}$ binding protein involved in the regulation of lactose biosynthesis as a component of lactose synthetase [7]. (Permyakov \& Berliner, 2000). It is very attractive for studies of the properties and structures of intermediate folding states since under acidic conditions $\alpha$-LA is a classic molten globule state, which is a compact and intermediate folding state between native and unfolded states, characterized by a conserved secondary structure but fluctuating tertiary structure. It has been observed that $\alpha$-LA interacts with lipid membranes and the protein can insert to lipid bilayer at $\mathrm{pH} 2.0$ [11]. $\alpha$-LA possesses several classes of fatty acid binding sites, and binds to 5-doxylstearic acid, stearic acid, and palmitic acid [12]. During the past decade, a novel biological function has been discovered for $\alpha$-LA. The multimeric $\alpha$-LA form isolated from the casein fraction of milk can induce apoptosis in tumor cells, but not in healthy cells [13]. The folding variant of $\alpha$-LA inducing apoptosis has been named
HAMLET/BAMLET (human/bovine $\alpha$-lactalbumin made lethal to tumor cells), which is a complex of the partially unfolded human/ bovine $\alpha$-LA and a necessary cofactor, oleic acid (C18:1). The iron-containing bioactive protein lactoferrin has antibacterial, antiviral, and antioxidant properties and also modulates iron metabolism and immune functions [14]. Lactoperoxidase, another bioactive protein, is part of a bactericidal system [15].

Bioactive peptides are inactive in the parent protein molecule sequence. In the structure of food proteins, inactivated form of the peptide can be activated by hydrolysis of protein molecules. For the production of bioactive peptides different hydrolysis procedures are exists. So far most common way for the production of bioactive peptides is enzymatic degradation. Enzymatic hydrolysis is used because it takes place under undenaturated conditions, so that nutritional properties are unaffected. Potential use of these hydrolysates includes but is not limited to the following aspects: improved stability at heat treatment, provide peptides specific for special diets, some functional properties are improved such as gelation, foaming and emulsifying capacity. The susceptibility to hydrolysis can be improved by using treatments such as heating, sulfitation, high pressure, changing the polarity of the environment and esterification, biological conversion through bacterial fermentation [16-19]. Therefore, physical and chemical treatments can induce a series of physicochemical changes which significantly influence state and stability of native proteins. Using pancreatic enzymes, particularly trypsin, chymotrypsin, pancreatin and pepsin with/withouth different combinations of bacterial and fungal origin proteinases, bioactive peptides that have different properties depending on the differences between the amino acid sequences, dimensions and amino acidstructure contained in carboxy / amino terminus can be produced $[20,21]$. For instance, with the combination of pepsin, trypsin, chymotrypsin, pancreatin, elastase and carboxypeptidase, Angiotensin Converting Enzyme (ACE) inhibitor peptides that have different levels have IC50 values than alpha-laktoglubul and beta-lactalbumin can be produced [22-24].

\section{Nanoencapsulation Studies for Delivery of Bioactive Peptides}

Many nutraceutical and functional food components would benefit from being encapsulated in appropriate edible delivery systems, including vitamins, probiotics, prebiotics, omega-3 fatty acids, plant extracts, antimicrobials, antioxidants, flavors, colors, and minerals. These active ingredients in foods must remain fully functional and be transported and discharged appropriately to have the desired nutritional effect. Many bioactive ingredients are prone to degradation and can interact with other food components resulting in loss of bioavailability [20]. Neri et al. [25] and thus there is a need to protect them throughout their shelflife as both an ingredient and in fortified food products, with the specific food systems without affecting the sensory properties, colour or flavour of food products. Nanoencapsulation of bioactive peptides is a new but promising concenpt. Improving their bioavailability by using nano delivery systems has been investigating. 
Since the effect of particle size on texture has a great importance, the addition of large particles is undesirable in most cases. The small particle size makes nanocapsules well suited for inclusion in food matrix [26,27]. Recent studies have revelaled that emulsion-based delivery systems are particularly suitable as they are toxicological safety and can be fabricated from food applicable components (e.g., oil, water, surfactants, and proteins). Possibility of large-scale production using economic processing operations such as high-pressure homogenization is another advantage of Nanoemulsions [28]. After ingestion, nanoemulsion droplets readily disperse in stomach to small droplet of nanoemulsion, which promotes wide distribution of the encapsulated bioactive throughout the GI condition [29]. Due to its small droplet size, nanoemulsions appear transparent or translucent, and were more stable against aggregation, flocculation, and coalescence and compared with microemulsions. The physicochemical properties of nanoemulsions are interesting for practical applications because of its small droplet size and long term stability.

In 1999, soy protein based multiple emulsion was developed to nanoencapsulate immunoglobulin G (IgG) [30]. Encapsulation of IgG in the multiple emulsion resuşted in an increased stability against acid ( $\mathrm{pH} 2.0)$ and alkali ( $\mathrm{pH}$ 12.0). Lactoferrin, minor protein component of whey, was found to contain antimicrobial peptides [31]. Lactoferrin was stabilized in a multiple emulsion formed by liposomal encapsulation system [32]. The lactoferrin nanoliposomes showed significant stability in simulated gastrointestinal juice at $37^{\circ} \mathrm{C}$ for $4 \mathrm{~h}$. Recently [33] investigated the encapsulation of lactoferrin in $\mathrm{W} / \mathrm{O} / \mathrm{W}$ nanoemuslion systems. After storage of the optimized multiple nanoemulsions (produced with Softisan) throughout 50 days, no leaching was oberved and moreover the free and encapsulated lactoferrin both showed significantly high antimicrobial acvitivites against Listeria inoccua and Staphylococcus aureus.

Nanoencapsulation of bioactive peptides is also studied in pharmaceutical industry especially for the delivery of therapeutic peptides. Peptide-drug nanofibers were formed ant htis formed nanofiber was found to protect the amphiphilic peptide dalargin from degradation in plasma [34]. In another study, [35] (2013) used liposome-peptide nanodelivery system for the treatment of Multiple Sclerosis (MS). Study was conducted on Dark Agouti rats revelaed that immunodominant peptides of the Myelin Basic Protein (MBP) encapsulated in mannosylated small unilamellar vesicles offered promising effects for MS treatment.

\section{Conclusion}

The future prospects are within the general theme foods for health and aims to obtain modified whey protein with improved functional properties. It is important to establish the relationship between structure and function of most important two whey proteins, for a better understanding of their susceptibility to enzymatic reactions; to obtain new, safe and natural ingredients (bioactive peptides) in order to develop food with multiple benefits for human body; to nanoencapsulate resulting bioactive peptides in order to improve bioavailability, and protect the stability of bioactive compounds during processing, storage and distribution; to control the rate of resulting bioactive peptides release; to obtain food applicable nano-carrier systems; to obtain background for the production of interactive foods which can allow consumers to modify the food with health benefits.

\section{References}

1. Renner E, Abd El-Salam MH. Ultrafiltration of whey. In Application of Ultra filtration in the Dairy Industry. New York: Elsevier Science; 1991. p.217-314.

2. Hambling SG, McAlpine AS, Sawyer L. Advanced Dairy Chemistry volume1: Proteins. Fox PF, editor. London: Elsevier Applied Science; 1992. P. 141-190.

3. McSweeney P, Fox PF. Dairy Chemistry: Proteins. 3rd ed. New York; Kluwer Academic; 2003.

4. Phillips LG, Whitehead DM, Kinsella J. Structure-function properties of food proteins. San Diego, California: Academic Press Inc; 1994

5. Kinsella JE, Whitehead DM, Brady J et al. Milk proteins: Possible relationships of structure and function. In: Fox PF, editor. Developments in Dairy Chemistry. London; 1989; 4. p. 131-172.

6. Sawyer L. $\beta$-Lactoglobulin. In: Fox PF, McSweeney P, editors. Advanced Dairy Chemistry I. The Netherlands: Kluwer Amsterdam; 2003.

7. Permyakov EA, Berliner LJ. $\alpha$-Lactalbumin. In: structure and function. London: Kluwer Academic/Plenum Publishers. 2000.

8. Lametti S, Rasmussen P, Frøkioer H, Ferranti P, Addeo F, Bonomi F. Proteolysis of bovine $\beta$-lactoglobulin during thermal treatment in subdenaturing conditions highlights some structural features of the temperatures-modified protein and yields fragments with low immunoreactivity. European Journal of Biochemistry. 2002; 269(5): 1362-72.

9. Said HM, Ong DE, Shingleton JL. Intestinal uptake of retinol: Enhancement by bovine milk beta-lactoglobulin. Am J Clin Nutri. 1989; 49(4): 690-4

10. Tawa NE, Goldberg AL. Suppression of muscle protein turnover and amino acid degradation by dietary protein deficiency. Journal of Physiology Endocrinology \& Metabolism. 1992; 263: 317-25.

11. Cawthern KM, Permyakov EA, Berliner LJ. Membrane-bound states of $\alpha$-lactalbumin: implications for the protein stability and conformation. Protein Science. 1996; 5(7): 1394-405.

12. Cawthern KM, Permyakov, Berliner LJ, Mahesh Narayan, Dipankar Chaudhri, Eugene A. Interactions of $\alpha$-lactalbumin with fatty acids and spin label analogs. The Journal of Biological Chemistry. 1997; 272: 30812-6.

13. Svensson M, Håkansson A, Mossberg AK, Linse S, Svanborg C. Conversion of $\alpha$-lactalbumin to a protein inducing apoptosis. PNAS2000; 97(8): 4221-6.

14. Walzem RL, Dillard CJ, German JB. Whey components: Millenia of evolution create functionalities for mammalian nutrition. What we know and what we may be overlooking. Critical Reviews in Food Science and Nutrition. 2002; 42(4): 353-75.

15. De Wit JN. Nutritional and functional characteristics of whey proteins in food products. Journal of Dairy Science. 1998; 81(3): 597-608.

16. Schmidt DG, Van Markwijk BW. Enzymatic hydrolysis of whey proteins. Influence of heat-treatment of $\alpha$-lactalbumin and $\beta$-lactoglobulin on their proteolysis by pepsin and papain. Netherland Milk Dairy Journal. 


\section{3; 47: 15-22.}

17. Kananen A, Savolainen J, Myllykoski L, Makinen J, Perttila U, PihlantoLeppala A. Influence of chemical modification of whey protein conformation on hydrolysis with pepsin and trypsin. International Dairy Journal. 2000; 10(10): 691-697.

18. Pintado ME, Pintado Ana E, Malcata XF. Controlled whey protein hydrolysis using two alternative proteases. Journal of Food Engineering. 1999; 42(1): 1-13.

19. Stănciuc N, I van der Plancken, Hendrickx M, Gabriela Rotaru. Denaturation impact in susceptibility of $\beta$-lactoglobulin to enzymatic hydrolysis: a kinetic study. Revue Roumaine de Chimie. 2008; 53(10): 921-9.

20. Korhonen H, Pihlanto-Leppälä. Milk Protein-Derived Bioactive Peptides- Novel Opportunities For Health Promotion, Bulletin of IDF. 2000; 363: 17-26.

21.Pihlanto-Leppälä A. Bioctive Peptides Derived From Bovine Whey Proteins: Opioid and Ace-Inhibitory Peptides. Trends in Food Sci. and Technol. 2000; 11(9-10): 347-56.

22. Mullally MM, Meisel H, FitzGerald RJ. Identification of a novel angitensin-I-converting enzyme inhibitory peptide corresponding to a tryptic fragment of bovine $\beta$-lactoglobulin. FEBS Lett. 1997; 402(23): 99-101.

23. McDonagh D, FitzGerald RJ. Production of caseinophosphopeptides (CPPs) from sodium caseinate using a range of commercial protease preparations. InternationalDairy Journal. 1998; 8(1): 39-45.

24. Pihlanto-Leppälä A, Koskinen P, Piilola K, Tupasela T, Korho H. Angiotensin I-converting enzyme inhibitory properties of whey protein digests: Concentration and characterization of active peptides. Journal of Dairy Research. 2000; 67(1): 53-64.

25. Neri DFM, Balcão VM, Carneiro-da-cunha, Carvalho Jr LB, Teixeira JA. Immobilization of $\beta$-galactosidase from Kluyveromyces lactis onto a polysiloxane-polyvinyl alcohol magnetic (mPOS-PVA) composite for lactose hydrolysis. Catalysis Communications. 2008; 9(4): 2334-9.
26. Chobert JM, Briand L, Dufour E, Dib R, Dalgalarrondo M, Haertle T. How to increase $\beta$-lactoglobulin susceptibility to peptic hydrolysis. Journal of Food Biochemistry. 1996; 20(4): 439-62.

27. Augustin MA, Sanguansri L. Encapsulation of Bioactives. Food Materials Science. 2008; 3: 577-601.

28. McClements DJ, Aguilera JM, Troncoso. Fabrication, characterization and lipase digestibility of food-grade nanoemulsions. Food Hydrocolloids. 2012; 27(2): 355-63.

29. Talegaonkar S, Mustafa G, Akhter S, Iqbal ZI. Design and development of oral oil-in-water nanoemulsion formulation bearing atorvastatin: in vitro assessment, Journal of Dispersion Science and Technology. 2010; 31(5): 690-701.

30. Chen CC, Tu YY, Chang HM. Efficiency and protective effect of encapsulation of milk emulsion. J Agric Food Chem. 1999; 47(2): 407-10.

31. Tomita M, Takase M, Wakabayashi. Antimicrobial peptides of lactoferrin. Adv Exp Med Biol. 1994; 357: 209-18.

32. Guan R, Ma J, Wu Y, Lu F, Xiao C, Jiang H, et al. Development and characterization of lactoferrin nanoliposome: cellular uptake and stability. Nanoscale Res Lett. 2012; 7(1): 679.

33. Balcão VM, Costa CI, Matos CM, Moutinho CG, Amorim M, Pintado $\mathrm{ME}$, et al. Nanoencapsulation of bovine lactoferrin for food and biopharmaceutical applications. Food Hydrocolloids. 2013; 32(2): 425-31.

34. Mazza M, Notman R, Anwar J, Rodger A, Hicks M, Parkinson G, et al. Nanofiber-based delivery of therapeutic peptides to the brain. ACS Nano. 2013; 7(2): 1016-26.

35. Belogurov Jr AA, Stepanov AV, Smirnov IV, Milamed D, Bacon A, Mamedov ME, et al. Liposome-encapsulated peptides protect against experimental allergic encephalitis. FASEB Journal. 27(1): 222-31. 